\title{
Animal Welfare Certification For Laying Hens: Compliance With The Legal Prohibition Of Mistreatment In Brazil
}

\author{
Yuri Fernandes Lima \\ Maestro en Derecho Animal \\ Universidade Federal de Bahia, Brazil
}

Recommended citation. LIMA Y.F., Animal Welfare Certification For Laying Hens: Compliance With The Legal Prohibition Of Mistreatment In Brazil, dA. Derecho Animal (Forum of Animal Law Studies) 10/1 (2019) - DOI https://doi.org/10.5565/rev/da.374

\begin{abstract}
This article aims to analyze the effectiveness of animal welfare certification for compliance with the legal prohibition of cruelty and mistreatment in the egg industry. I analyze the conditions of conventional cage systems, the legal protection to laying hens in Brazil, and the animal welfare certification for laying hens. I conclude that the existing welfare certification for laying hens is enough to ensure the accomplishment of the law, but it is necessary to consider ways to stimulate producers to obtain this certification and, therefore, to change their mode of production, providing a high level of welfare for laying hens.
\end{abstract}

Keywords: egg industry; laying hens; cruelty and ill-treatment; animal welfare certification..

Resumen - Certificación de bienestar animal para gallinas ponedoras: cumplimiento de la prohibición legal de maltrato en Brasil

Este artículo pretende analizar la efectividad de la certificación de bienestar animal para ajustarse a la prohibición legal de crueldad y maltrato en la industria del huevo. Analizo las condiciones de los sistemas convencionales de jaulas, la protección legal de las gallinas ponedoras en Brasil, y la certificación de bienestar animal para las gallinas ponedoras. Concluyo que la existencia de certificación de bienestar es suficiente para garantizar el cumplimiento de la ley, pero es necesario considerar vías para estimular la obtención de estos certificados por parte de los productores y, por lo tanto, cambiar su modo de producción, proporcionando un nivel alto de bienestar para las gallinas ponedoras.

Palabras clave: industria del huevo; gallinas ponedoras; crueldad y malos tratos; certificación de bienestar animal. 


\title{
Table of contents
}

\author{
Introduction \\ 1. Exploitation of Laying Hens \\ 2. Legal Protection of Laying Hens in Brazil \\ 3. Welfare Certification for Laying Hens - Certified Humane ${ }^{\circledR}$ \\ 4. The Role and the Importance of the Consumer \\ Conclusion
}

\section{Introduction}

This article has as its theme the animal welfare regarding the breeding of laying hens in Brazil. It is the result of the master's dissertation that I have conducted at the Federal University of Bahia ${ }^{1}$. The research is justified by the fact that $95 \%$ of a hundred million hens exploited for egg industrial production in the country are confined in battery cages ${ }^{2}$, which is a system that inflicts extreme mistreatment of these animals. The battery cages are so tight and tiny that they cannot express their natural behaviors, like hunker down, walk, run, fly, open and stretch their wings. They also don't have access to pasture and can't scratch, feed, bath, sunbath, lay eggs in nests and perch.

On the other hand, Brazilian legislation prohibit cruelty and mistreatment of animals, specially the Federal Constitution ${ }^{3}$, the Environmental Crimes Law ${ }^{4}$ and the Decree $n^{0} 24.645 / 34^{5}$. Although there is such a legal framework, as well as international guidelines and non-statutory standards, in practice, laying hens are still being subjected to mistreatment.

In this context, the problem of this research is how to ensure compliance with and the effectiveness of the Brazilian legislation and the hypothesis is the welfare certification for laying hens. In other words, I would like to verify if the welfare certification would be enough to ensure compliance with and the effectiveness of the Brazilian legislation that prohibit cruelty and mistreatment.

I don't advocate the welfarist vision, but I believe, along with some authors such as Robert Garner ${ }^{6}$ and Carlos Naconecy ${ }^{7}$ that, as we walk towards abolitionism - because I share the idea that the animal exploitation is not justified under any circumstances - it is necessary to improve the conditions of animals that are alive and suffering today.

The objective of this article is to analyze the effectiveness of welfare certification for compliance with the legal prohibition of cruelty and mistreatment; this will be accomplished by examining: (i) the conditions of conventional cage systems, in order to confirm the existence of mistreatment; (ii) the legal protections afforded to laying hens in Brazil; and, (iii) the animal welfare certification for laying hens, in order to verify if it has the effect of ensuring compliance with the legislation that prohibits cruelty and mistreatment.

I conclude that the existing welfare certification for laying hens provided by HFAC - Humane Farm Animal Care is enough to ensure the accomplishment of the law as it has standards and rules to be followed that allow the laying hens to exert their natural behavior on the one hand, and, on the other hand, prohibit practices that prevent such behavior. Thus, these HFAC standards provide a high level of well-being for these birds.

\footnotetext{
${ }^{1}$ LIMA, Y.F., Certificação de Bem-Estar Animal na Indústria de Ovos. 2018. Dissertação (Mestrado em Direito) - Núcleo de pesquisa e extensão em Direito ambiental e animal, Universidade Federal da Bahia (Salvador 2018).

2 BAUDUCCO anuncia política livre de gaiolas. Fórum Animal. 2018. Available in: https://www.forumanimal.org/singlepost/2018/03/29/Bauducco-anuncia-pol\%C3\%ADtica-livre-de-gaiolas (Site visited on: Mar. 29th 2018).

${ }_{3}^{3}$ BRASIL. Constituição da República Federativa do Brasil de 1988. Available in:
http://www.planalto.gov.br/ccivil 03/Constituicao/Constituicao.htm (Site visited on: Sep. 17th 2017).

${ }^{4}$ BRASIL. Lei $\mathrm{n}^{\circ}$ 9.605, de 12 de fevereiro de 1998. Dispõe sobre as sanções penais e administrativas derivadas de condutas e atividades lesivas ao meio ambiente, e dá outras providências. Diário Oficial [da] República Federativa do Brasil, Brasília, DF, 12 fev. 1998. Available in: http://www.planalto.gov.br/ccivil 03/Leis/L9605.htm (Site visited on: Sep. 17th 2017).

${ }^{5}$ BRASIL. Decreto ${ }^{\circ}$ 24.645, de 10 de julho de 1934. Estabelece medidas de proteção aos animais. Diário Oficial [da] República Federativa do Brasil, Rio de Janeiro, RJ, 10 jul. 1934. Available in: http://www.planalto.gov.br/ccivil 03/decreto/19301949/d24645.htm (Site visited on: Sep. 17th 2017).

${ }^{6}$ GARNER, R., Ideologia política e o status jurídico dos animais. Revista Brasileira de Direito Animal, v. 9, n. 17, 2014. Available in: https://portalseer.ufba.br/index.php/RBDA/article/view/12973/9280 (Site visited on: Nov. 5th 2017).

${ }^{7}$ NACONECY, C., Bem-Estar Animal ou Libertação Animal? Uma Análise Crítica da Argumentação AntiBem-Estarista de Gary Francione. Revista Brasileira de Direito Animal, v. 4, n. 5, 2009, p. 235-267. Available in: https://portalseer.ufba.br/index.php/RBDA/article/view/10633/7678 (Site visited on: Nov. 15th 2017). 
However, it is necessary to consider ways to stimulate producers to obtain this certification and, therefore, to change their mode of production, providing a high level of welfare for laying hens. This could be economically advantageous. Researches made with consumers from all over Brazil show that, regardless of the social class, most of them care about animal welfare and would prefer to buy certified eggs, albeit more expensive. In addition, the productivity increase is proportional to the animal welfare increase.

\section{Exploitation of Laying Hens}

Yuval Harari, Peter Singer and Tom Regan explain that in standard egg industry breeding practices, four to ten hens are confined in cages so small that laying hens cannot spread their wings ${ }^{8} 9$ 10; this cruel mistreatment is a practice designed to reduce costs and increase profits ${ }^{11}$.

Singer explains that this battery cages system or batteries of cages, is named "not because there's something electric in them, but because the original meaning of the word 'battery' is a set of similar units connected to an equipment"'12. According to Jonathan Safran Foer, "such cages are stacked between three and nine tiers high - Japan has the largest farm in the world, with cages stacked eighteen tiers high - in windowless sheds." 13

Despite being the most criticized, the battery cages system it is the most globally-used system in poultry farming ${ }^{14}$.

The newborn chicks are separated by sex; the 150 million male chicks born each year are "useless" to the egg industry and, are killed on the same day they are born. Most of the time they are thrown alive in trash cans to suffocate to death or are grinded alive to feed their sisters ${ }^{15} 16$.

As they are locked in tiny cages since they are born, the hens become extremely aggressive and therefore commit cannibalism ${ }^{17}$. To solve this problem, the egg industry, prioritizing profit, over welfare, has created the debeaking procedure, which consists of cutting the upper beak of the female newborn chick $^{18}$. A blowtorch, which burned the top of the beak, was initially used for debeaking, but was then replaced by applying a soldering iron to the beak; this technique was subsequently replaced by the current method of applying, hot knifes to the beak - in Brazil, hens are debeaked by a scorching 595-degrees-Celsius blade ${ }^{19}$. The laying hens are debeaked twice. First around five to ten days after birth and second, with twelve to eighteen weeks of age ${ }^{20}$ and the beak removal results is chronic pain when made after ten days of age ${ }^{21}$.

Approximately fifteen female chicks are debeaked per minute; this rapid pace often results in sloppy cutting and, thus serious injury, to the bird: "There are many cases of burned nostrils and severe mutilations due to incorrect procedures, which unquestionably influence feeding behavior and the production factors and cause acute and chronic pain" 22 . For several weeks after sustaining an injury by debeaking, a mutilated hen will eat less and lose weight ${ }^{23}$.

After separated and debeaked, the hens are placed in battery cages, which are in enclosed sheds equipped with artificial lighting; these hens are therefore never exposed to natural sunlight ${ }^{24}$. Because battery cages are stacked in tiers, the excrement of hens on higher tiers falls directly on the hens below ${ }^{25}$. This waste accumulates until a person cleans the cages, which means hens in lower tiers may be covered in excrement

\footnotetext{
${ }^{8}$ HARARI, Y. N., Sapiens - Uma Breve História da Humanidade (Porto Alegre 2016) 352.

${ }^{9}$ SINGER, P., Libertação Animal (São Paulo 2010) 160.

${ }^{10}$ REGAN, T., Jaulas vazias: encarando o desafio dos direitos animais (Porto Alegre 2006) 115.

${ }^{11}$ SINGER, P., op. cit. (2010) 163.

12 Ibidem., p. 159 .

${ }^{13}$ FOER, J. S., Comer Animais (Rio de Janeiro 2011) 69.

${ }^{14}$ CARVALHO, L.C. et al., Bem-Estar na Produção de Galinhas Poedeiras - Revisão de Literatura. Revista Científica de Medicina Veterinária - Ano XIV - Número 28 - Janeiro de 2017. Available in: http://revistas.bvs-vet.org.br/rcemv/article/view/32575/40831 (Site visited on: Oct. 24th 2017) 04.

${ }^{15}$ SINGER, P., op. cit. (2010) 158.

${ }^{16}$ REGAN, T., op. cit. (2006) 116.

${ }^{17}$ CARVALHO, L.C. et al., Bem-Estar na Produção de Galinhas Poedeiras - Revisão de Literatura. Revista Científica de Medicina Veterinária - Ano XIV - Número 28 - Janeiro de 2017. Available in: http://revistas.bvs-vet.org.br/rcemv/article/view/32575/40831 (Site visited on: Oct. 24th 2017) 04.

${ }^{18}$ HUMANE FARM ANIMAL CARE. Padrões da HFAC para a Criação de Galinhas Poedeiras (2018) 32.

${ }^{19}$ EMPRESA BRASILEIRA DE PESQUISAS AGROPECUÁRIA (EMBRAPA). Alternativas e Consequências da Debicagem em Galinhas Reprodutoras e Poedeiras Comerciais. Concórdia, SC: Embrapa Suínos e Aves (2008). Available in: http://www.infoteca.cnptia.embrapa.br/bitstream/doc/444166/1/doc128.pdf (Site visited on: Jun. 15th 2018) 12.

${ }^{20}$ Ibidem., 157-158.

${ }^{21}$ HUMANE FARM ANIMAL CARE. Padrões da HFAC para a Criação de Galinhas Poedeiras. (2018) 32.

${ }^{22}$ SINGER, P. Libertação Animal (São Paulo 2010) 148.

${ }^{23}$ SINGER, P., op. cit. (2010) 149.

${ }^{24}$ SINGER, P., op. cit. (2010) 158-159.

${ }^{25}$ REGAN, T., Jaulas vazias: encarando o desafio dos direitos animais (Porto Alegre 2006) 115.
} 
for long periods ${ }^{26}$. The cage floors are made of tilted wire, which enables scrolling of the eggs for channels in front of cages. Laying hens are not anatomically adapted to standing on wire for years; along with great discomfort, the wire cause abnormalities and sores to develop in their legs and nails. Further, without a solid surface to trim their nails, the hens' nails grow and eventually curl around the wire, permanently attaching the hens to a tilted wire torture 2728 .

Brittle bones are another common problem exhibited by laying hens bred in battery cages. According to a study with approximately 3,000 birds, 98 percent had broken bones, and an average of six breaks each. The consistency of bones of battery hens is akin to potato crisps ${ }^{29}$. Such a problem is raised by the amount of eggs that the chickens are forced to lay artificially, so that the egg industry has as much profit. This is because the calcium present in the egg shell is taken from the medullary bone of chickens and exceeds thirty times their body reserves ${ }^{30}$.

Regan tells the very common practice of forced molting, where the laying hens, so that they initiate another laying cycle, are denied food for ten to fourteen days, during which time they can lose as much as 25 percent of their body weight and which as many as 10 percent of laying hens die $^{31}$.

When hens die before the end of the production cycle of two years, their bodies stay in the cages with live chickens and their eggs until an employee remove them. If the hens can survive after two years, they are then sold to slaughterhouses to market their meat ${ }^{32}$.

Laying hens are seen by the poultry industry as an egg producing machine or converting machines of feeding stuff into eggs ${ }^{33}$. The egg industry practices that prevent the natural behavior of laying hens and also are extremely cruel and painful to them, causing a lifetime of suffering, are the following: tiny cages; lack of contact with ground; non-interaction with other birds; forced molting; cannibalism ${ }^{34}$ and consequent debeaking ${ }^{35}$; no space for physical exercises, scratch and dust bath; lack of access to nests and perches; impossibility of escape and fight against predators; inability to spread their wings; discomfort of spending a life stand, without being able to squat down and spend a life under a metal wire floor that mutilates the claws.

In Brazil, which 95 percent of the one hundred million chickens exploited in industrial production are confined in battery cages ${ }^{36}$ and each cage confines five to ten chickens and provides a space smaller than an A4 sheet of paper for each bird ${ }^{37}, 34$ billion eggs were laid ${ }^{38}$ in 2013 and, that same year, 168 eggs were consumed per person.

\section{Legal Protection of Laying Hens in Brazil}

The first Brazilian law concerning animal cruelty was the Decree-Law $n^{\circ} 16.590$, of September $10^{\text {th }}$, $1924^{39}$, which prohibited bull fights, calf fights, rooster fights and canary fights among other diversions causing suffering to animals ${ }^{40}$.

\footnotetext{
${ }^{26}$ SINGER, P., op. cit. (2010) 161.

${ }^{27}$ Ibidem., 161.

${ }^{28}$ REGAN, T., op. cit. (2006) 115.

${ }^{29}$ GARNER, R., Animals, Politics and Morality (Issues in Environmental Politics). (Manchester 1993) 102.

${ }^{30}$ FARM ANIMAL WELFARE COUNCIL. Opinion on Osteoporosis and Bone Fractures in Laying Hens. December 2010. Available in: http://webarchive.nationalarchives.gov.uk/20110909181139/http://www.fawc.org.uk/pdf/bone-strength-opinion-101208.pdf (Site visited on: Jan. 7th 2018) 03-04.

${ }^{31}$ REGAN, T., Jaulas vazias: encarando o desafio dos direitos animais (Porto Alegre 2006) 116.

32 SINGER, P., Libertação Animal (São Paulo 2010) 157.

${ }^{33}$ SINGER, P., Libertação Animal (São Paulo 2010) 157.

${ }^{34}$ CARVALHO, L.C. et al. Bem-Estar na Produção de Galinhas Poedeiras - Revisão de Literatura. Revista Científica de Medicina Veterinária - Ano XIV - Número 28 - Janeiro de 2017. Available in: http://revistas.bvs-vet.org.br/rcemv/article/view/32575/40831 (Site visited on: Oct. 24th 2017) 04.

35 CARVALHO, L.C., op. cit. (2017) 02

36 BAUDUCCO anuncia política livre de gaiolas. Fórum Animal. 2018. Available in: https://www.forumanimal.org/singlepost/2018/03/29/Bauducco-anuncia-pol\%C3\%ADtica-livre-de-gaiolas (Site visited on: Mar. 29th 2018).

${ }^{37}$ CARGILL, fabricante das maioneses Liza e Maria, se compromete a acabar com as gaiolas em bateria para galinhas. Fórum Animal. 2017. Available in: https://www.forumanimal.org/single-post/2017/01/13/Cargill-fabricante-das-maioneses-Liza-e-Maria-secompromete-a-acabar-com-as-gaiolas-em-bateria-para-galinhas (Site visited on: Dec. 24th 2017).

${ }^{38}$ I adopt the expression laid instead of produced, therefore I consider the laying hens as legal subjects enslaved instead of assets.

${ }^{39}$ BRASIL. Decreto-Lei $\mathrm{n}^{\circ} 16.590$, de 10 de setembro de 1924. Aprova o regulamento das casas de diversões públicas. Diário Oficial [da] República Federativa do Brasil, Rio de Janeiro, RJ, 10 set. 1924. Available in: http://www2.camara.leg.br/legin/fed/decret/19201929/decreto-16590-10-setembro-1924-509350-norma-pe.html (Site visited on: Sep. 17th 2017).

${ }^{40}$ PONTES, B.C., Lei no 11.101/11: Análise das Políticas Públicas para Animais Domésticos e Domesticados no Município de Porto Alegre. Revista Brasileira de Direito Animal, v. 7, p. 118-144, 2012. Available in:
} https://portalseer.ufba.br/index.php/RBDA/article/view/8419/6033 (Site visited on: Oct. 16th 2017, p. 119). 
On July $10^{\text {th }}, 1934$, was promulgated the Decree $n^{\circ} 24.645^{41}$; article 3 defines an extensive list of practices that could qualify as "mistreatment." The most important innovation of this Decree was the recognition of the status of legal subjects to animals ${ }^{42}$, in addition to pioneering the animalist protection vocation in Brazilian legal system and the consequent need for respect for interpreters of the Federal Constitution from $1988^{43}$.

Then came the Decree-Law $n^{0} 3.688$, of October $3^{\text {rd }}, 1941^{44}$, the Law of Criminal Misdemeanors, which provides, in its article 64, prison sentence or a fine for those who are cruel to animals or subject them to excessive work. For Edna Cardozo Dias, this device includes almost all types of cruelty against animals contained in article 3 of Decree $\mathrm{n}^{\circ} 24.645 / 34^{45}$.

In 1998, the Environmental Crimes Law was promulgated; article 32 makes it a crime to "abuse, mistreatment, injure or mutilate wild animals, domestic or domesticated, native or exotic" ${ }^{46}$. However, this law does not criminalize killing domestic animals - rather, it is only prohibited to cause the death of a wild animal under article 29. ${ }^{47}$, Although the Environmental Crimes Law is convenient for the meat industry (because if the article 29 typified domestic animal killing, such industry would go out of business), such organizations can still be prosecuted under article 32 because the banned mistreatment is present in the meat, dairy and eggs industries.

The Federal Constitution from 1988, in article 225, paragraph 1, section VII, prohibits practices which submit animals to cruelty and, thus, recognizes that animals are subjects of law, at least with the right not to be subjected to cruelty ${ }^{48}$. Likewise, Carlos Raul Brandão Tavares believes that "the Constitution of 1988 has acknowledged the animal dignity as a principle of constitutional order" 49 . For Danielle Tetü Rodrigues, the constituent's intention is protecting animals and raises them to a special position ${ }^{50}$.

Brazil is still in its infancy regarding animal welfare legislation. However, there are a few Bills of Law awaiting judgement in the legislative houses of all spheres of the country on this subject. In this regard, I quote the Bill of Law $\mathrm{n}^{\mathrm{o}} 22.223 / 2017^{51}$ that prohibits the breeding of animals in confinement system in the State of Bahia, and the Bill of Law 215/2007, which creates the Federal Code on Animal Welfare ${ }^{52}$.

The Bill of Law 215/2007, in its article 100, caption, prohibits the battery cages system and, in its first paragraph, prohibits debeaking of birds. However, the given Bill of Law is awaiting judgment for more than ten years to be put to the vote.

With regard to secondary normative acts, it is important to mention (i) Normative Ruling of the Ministry of Agriculture, Livestock Development and Supplying $\mathrm{n}^{\mathrm{o}} 3$, of January $17^{\text {th }}, 2000^{53}$, regulating the preslaughter management procedures (insensibility) and humanitarian slaughter of animals for butchers; (ii) Normative Ruling of the Ministry of Agriculture, Livestock Development and Supplying $\mathrm{n}^{\circ}$ 56, of November $6^{\text {th }}, 2008^{54}$, which establishes general Procedures of Recommendations of Best Welfare Practices for Animal

${ }^{41}$ BRASIL. Decreto $n^{\circ}$ 24.645, de 10 de julho de 1934. Estabelece medidas de proteção aos animais. Diário Oficial [da] República Federativa do Brasil, Rio de Janeiro, RJ, 10 jul. 1934 Available in: http://www.planalto.gov.br/ccivil 03/decreto/19301949/d24645.htm (Site visited on: Sep. 17th 2017).

${ }^{42}$ PONTES, B.C., op. cit. (2012) p. 120.

${ }^{43}$ CUREAU, S., A Proibição Constitucional de Práticas Cruéis Contra Animais: um Mandamento Definitivo que Dispensa Qualquer Ponderação de Direitos. In: PURVIN, Guilherme (Org.). Direito Ambiental e Proteção dos Animais (São Paulo 2017$) 91$.

${ }^{44}$ BRASIL. Decreto-Lei no 3.688, de 3 de outubro de 1941. Lei das Contravenções Penais. Diário Ofícial [da] República Federativa do Brasil, Rio de Janeiro, RJ, 03 jan. 1941. Available in: http://www.planalto.gov.br/ccivil 03/decreto-lei/Del3688.htm (Site visited on: Sep. 17th 2017).

${ }^{45}$ DIAS, E.C., A evolução da legislação de proteção animal e os movimentos sociais na pós-modernidade. In: DIAS, Edna Cardozo; SALLES; Álvaro Angelo (Org.). Direito animal: a defesa dos animais sob uma perspectiva ética, histórica e jurídica (Belo Horizonte 2017) 56.

${ }^{46}$ BRASIL. Lei $\mathrm{n}^{\circ}$ 9.605, de 12 de fevereiro de 1998. Dispõe sobre as sanções penais e administrativas derivadas de condutas e atividades lesivas ao meio ambiente, e dá outras providências. Diário Oficial [da] República Federativa do Brasil, Brasília, DF, 12 fev. 1998. Available in: http://www.planalto.gov.br/ccivil 03/Leis/L9605.htm (Site visited on: Sep. 17th 2017).

${ }^{47}$ GORDILHO, H. J., Abolicionismo animal (Salvador 2008) 141-148.

${ }^{48}$ LEVAI, L.F., Direito dos animais (Campos do Jordão 2004) 137.

${ }^{49}$ TAVARES, Carlos Raul Brandão. O confinamento animal: aspectos éticos e jurídicos. 2012. Dissertação (Mestrado em Direito) Núcleo de pesquisa e extensão em Direito ambiental e animal, Universidade Federal da Bahia, Salvador, p. 12.

${ }^{50}$ RODRIGUES, D.T., Direito dos Animais e a Proteção Jurídica Brasileira. In: TOSTES, R.A.- REIS, S.T.J.- CASTILHO, V.V. (Org.). Tratado de Medicina Veterinária Legal (Curitiba 2017) 415.

${ }^{51}$ BAHIA. Projeto de Lei no $22.223 / 2017$. Proíbe a criação de animais em sistema de confinamento no Estado da Bahia. Available in: http://www.al.ba.gov.br/atividade-legislativa/proposicao/PL./22.223/2017 (Site visited on: Sep. 14th 2017).

52 BRASIL. Projeto de Lei $\mathrm{n}^{\mathrm{o}}$ 215, de 2007. Institui o Código Federal de Bem-Estar Animal. Available in: http://www.camara.gov.br/proposicoesWeb/fichadetramitacao?idProposicao=341067 (Site visited on: Sep. 07th 2017).

${ }_{53}$ MAPA - Ministério da Agricultura, Pecuária e Abastecimento. Instrução Normativa $\mathrm{n}^{\circ}$ 3, de 17 de janeiro de 2000. Aprova o Regulamento Técnico de Métodos de Insensibilização para o Abate Humanitário de Animais de Açougue. Available in: http://www.agricultura.gov.br/assuntos/sustentabilidade/bem-estar-animal/arquivos/arquivos-legislacao/in-03-de-2000.pdf (Site visited on: Sep. 10th 2017).

${ }^{54}$ MAPA - Ministério da Agricultura, Pecuária e Abastecimento. Instrução Normativa no 56, de 06 de novembro de 2008. Estabelece 
of Production and Economic Interest (REBEM); (iii) Ordinance of the Ministry of Agriculture, Livestock Development and Supplying $n^{\mathrm{o}}$ 524, of June $21^{\text {st }}, 2011^{55}$, which institutes the Permanent Technical Committee for Specific Studies on Animal Welfare in different areas of the Livestock Chain (CTBEA); and (iv) Technical Circular $n^{\circ} 49 / 2006$, of the Brazilian Agricultural Research Corporation (EMBRAPA), containing recommendations of "Best Manufacturing Practices in Commercial Position" 56.

However, the best practices referred above are more related to sanitary-hygienic and environmental aspects and entered an anthropocentric perspective, referring to the birds as "batches" and eggs as "products", whose quality must be guaranteed and ensured for human consumption. The alleged concern for the bird's welfare allows extremely cruel practices, such as debeaking. Furthermore, although it admits that "the welfare of laying hens housed in cage systems is a concern of the consumer market and has reflected the recent legislative changes that are occurring in some markets, like the European" ${ }^{157}$, it allows the cage system, since "in Brazil, there is still no specific legislation regarding animal welfare, considering the number of birds per cage" ${ }^{\prime 2}$. Thus, from the point of view of the laying hens' welfare, I think the current standards of the Brazilian Agricultural Research Corporation are not suitable.

Finally, there are no unified laws and protocols regarding animal welfare nor national nor international, making difficult the measurement and application of the criteria. Along these lines, the mandatory animal welfare certification becomes a measure that imposes itself to solve this problem.

\section{Welfare Certification for Laying Hens - Certified Humane ${ }^{\circledR}$}

As seen here, most laying hens in Brazil are confined in battery cages and have all their natural behaviors denied.

Notwithstanding the Federal Constitution of 1988, in its article 225, paragraph 1, section VII, prohibits cruelty, and Environmental Crimes Law typifies as a crime the mistreatment of animals, beyond the Law of Criminal Misdemeanors and Decree $\mathrm{n}^{\circ} 24.645 / 34$, that prohibits many practices regarded as mistreatment and cruelty. Therefore, laying hens are protected by national legislation against cruelty and mistreatment, although there are no specific laws, such as Bill of Law 215/2007, which expressly prohibits the battery cages system in Brazil.

In this way, it is important to assert how to ensure the effectiveness of the legislation which prevent cruelty and mistreatment of these birds, so that the welfare certification is a possibility.

The Certified Humane ${ }^{\circledR}$ is an animal welfare certification, granted by the Humane Animal Farm Care (HFAC), International NGO focused on improving the "lives of farm animals by establishing viable and reliable standards properly monitored for humanitarian food production and ensuring consumers that certified products meet these standards" ${ }^{\prime 5}$. In South America it is represented by the Certified Humane Brazil.

The Certified Humane Brazil Institute operates in partnership with the certifier Ecocert Brasil, which is accredited by the National Institute of Metrology, Quality and Technology (INMETRO) ${ }^{60}$, that is the federal autarchy ${ }^{61}$ responsible for accreditation ${ }^{62}$, that is the "third-party certification related to a conformity assessment body, communicating the formal demonstration of its competence to carry out specific conformity assessment tasks" 63 .

os procedimentos gerais de Recomendações de Boas Práticas de Bem-Estar para Animais de Produção e de Interesse Econômico $\begin{array}{llllll}\text { REBEM, abrangendo os sistemas de produção e e o transporte. Available } & \text { in: } \\ \text { http://www.agricultura.gov.br/assuntos/sustentabilidade/bem-estar-animal/arquivos/arquivos-legislacao/in-56-de-2008.pdf } & \text { (Site }\end{array}$ visited on: Sep. 10th 2017).

${ }^{55}$ MAPA - Ministério da Agricultura, Pecuária e Abastecimento. Portaria n ${ }^{\circ} 524$, de 21 de junho de 2011. Institui a Comissão Técnica Permanente para Estudos Específicos sobre Bem-Estar Animal nas Diferentes Áreas da Cadeia Pecuária. Available in: http://www.normasbrasil.com.br/norma/portaria-524-2011 233257.html (Site visited on: Sep. 10th 2017).

${ }_{56}$ EMPRESA BRASILEIRA DE PESQUISA AGROPECUÁRIA (EMBRAPA). Circular Técnica no 49/2006. Boas Práticas de Produção na Postura Comercial. Concórdia/SC, dezembro de 2006, ISSN 0102-3713. Available in: https://www.embrapa.br/suinose-aves/busca-de-publicacoes/-/publicacao/443776/boas-praticas-de-producao-na-postura-comercial (Site visited on: May 10th 2018). ${ }^{57}$ EMPRESA BRASILEIRA DE PESQUISA AGROPECUÁRIA (EMBRAPA). Circular Técnica $\mathrm{n}^{\circ}$ 49/2006. Boas Práticas de Produção na Postura Comercial. Concórdia/SC, dezembro de 2006, ISSN 0102-3713. Available in: https://www.embrapa.br/suinose-aves/busca-de-publicacoes/-/publicacao/443776/boas-praticas-de-producao-na-postura-comercial (Site visited on: May 10th 2018) 08.

${ }^{58}$ EMPRESA BRASILEIRA DE PESQUISA AGROPECUÁRIA, op. cit. (2006) 08

59 HUMANE FARM ANIMAL CARE. Padrões da HFAC para a Criação de Galinhas Poedeiras (2018) i.

${ }^{60}$ ORGANISMOS acreditados. Inmetro. Available in: http://www.inmetro.gov.br/organismos/resultado consulta.asp (Site visited on: May 18th 2018).

${ }^{61}$ O QUE é o Inmetro. Inmetro. Available in: http://www.inmetro.gov.br/inmetro/oque.asp (Site visited on: Jun. 22th 2018).

62 SOBRE Acreditação de Organismos de Certificação. Inmetro. Available in: http://www.inmetro.gov.br/credenciamento/sobre org cert.asp (Site visited on: May 18th 2018).

${ }^{63}$ COSTA-FÉLIX, R.P., - BERNARDES, A. T., (Org.). Metrologia Vol. 1: Fundamentos (Rio de Janeiro 2017) 256.

136 Derecho Animal. Forum of Animal Law Studies, vol. 10/1 
To obtain the Certified Humane ${ }^{\circledR}$, it should be noted, first, the Manual of Guidelines ${ }^{64}$ and, secondly, there are specific references for each species ${ }^{65}$, including the standards for laying hens ${ }^{66}$.

The standards for laying hens are divided into six parts: (i) food and water; (ii) environment; (iii) grassfed breeding standards and free-range; (iv) management; (v) health; and (vi) transport ${ }^{67}$.

With respect to the laying hens feeding, the forced molting is not allowed ${ }^{6869}$, since it's a clear practice of mistreatment. In addition, "it is prohibited to feed them with animal products" ${ }^{70}$, which prevents the use of new born chicks grinded alive to feed their sisters.

As for the environment, it shall meet the welfare needs for birds and their natural behaviors, as well as protect them from physical and thermal discomfort, fear and distress ${ }^{71}$.

All kinds of cages, such as battery cages, furnished or enriched, are expressly prohibited. In the aviary systems, all hens might have access to all levels of the housing system, always ${ }^{72}$. The HFAC standards for laying hens do not require that birds have access to external area or be bred in open air, although that would generate benefits for the hens' welfare and, therefore, can be encouraged ${ }^{73}$.

Other important notes about the environment are the abrasive papers close to feeders so that the claws do not grow to the point of harming the welfare of laying hens, no contact of birds to their excrement, no access of wild birds or rodents to external areas and the possibility of dust baths ${ }^{74}$, which is a natural behavior of the species ${ }^{75}$.

The standards indicate that lighting variation can help the birds to perform certain natural behaviors, such as foraging and dust bathing by increasing lighting levels over the beds or rest during the day by reducing lighting on perches and reducing the cannibalism risks because of the darkness inside the nests ${ }^{76}$.

Regarding the available space, hens must have enough freedom of movements so that the birds could easily stand, turn around and stretch wings and legs, as well as it must have enough space for them to perch and feel quietly without being disturbed repeatedly by other birds ${ }^{77}$.

Furthermore, the HFAC Standards establish minimum space per bird both inside the housing area ${ }^{78}$ and external area ${ }^{79}$. It is important to note such parameters as overcrowding implies mistreatment, so it is important to supervise the number of birds per square meter in all systems.

Also, in the section regarding the environment, there are provisions about nests and perches, which are strictly related to the natural behavior of birds, which does not exist in the cage systems. As for perches, they should be accessible to hens full-time, during day and night ${ }^{80}$.

Part 5 of the HFAC standards for laying hens refers to responsible management to ensure high level of animal welfare, and managers and employees must be highly trained, skilled and competent in animal management and welfare. ${ }^{81}$. Then it refers to monitoring and preventive actions for protection against pests, predators (wild birds, dogs and cats), rodents and flies ${ }^{82}$.

Part 6 of the HFAC standards refers to the laying hens' health, which must be protected from pain, injury and disease, with recurrent injuries being prohibited, attributed to the physical characteristics of the environment or handling procedures, such as foot injuries and nail wear ${ }^{83}$, typical injuries of cage systems. In the same direction, the standards determine that the conditions such as cannibalism, fractures and bone

\footnotetext{
${ }^{64}$ HUMANE FARM ANIMAL CARE. Manual de Diretrizes do Programa (2014).

${ }^{65}$ REFERENCIAIS. Instituto Certified Humane Brasil. Available in: http://certifiedhumanebrasil.org/referenciais/ (Site visited on: May 18th 2018).

${ }^{66}$ HUMANE FARM ANIMAL CARE. Padrões da HFAC para a Criação de Galinhas Poedeiras (2018).

${ }^{67}$ HUMANE FARM ANIMAL CARE, op. cit. (2018) iv-vi.

${ }^{68}$ HUMANE FARM ANIMAL CARE, op. cit. (2018) 02.

${ }^{69}$ Ibidem., 27.

${ }^{70}$ Ibidem., 02.

${ }^{71}$ Ibidem., 04.

${ }^{72}$ Ibidem., 04.

${ }^{73}$ Ibidem., 13.

74 Ibidem., 05.

75 "The dust bath is one of the 'comfort behaviors' of hens to keep their wings clean and in good condition. The hen moves around in the material (for example, sawdust or sand) moving its legs and wings, later swinging quickly and expelling the material. It is important to keep the feathers in good condition because it helps protect the hens against injury and to keep their body temperature." HUMANE FARM ANIMAL CARE, op. cit., 06.

${ }^{76}$ HUMANE FARM ANIMAL CARE. Padrões da HFAC para a Criação de Galinhas Poedeiras (2018) 07.

${ }^{77}$ HUMANE FARM ANIMAL CARE, op. cit. (2018) 08.

${ }^{78}$ HUMANE FARM ANIMAL CARE. Padrões da HFAC para a Criação de Galinhas Poedeiras (2018) 08.

${ }^{79}$ Ibidem., 13.

${ }^{80}$ Ibidem., 10.

${ }^{81}$ Ibidem., 20.

${ }^{82}$ Ibidem., 24.

${ }^{83}$ Ibidem., 25.
} 
deformations and trapped birds should be observed with attention ${ }^{84}$, as they are common problems in conventional cage systems caused by overcrowding and confinement conditions.

Debeaking is not allowed. However, beak trimming is permitted until the birds reach ten days of age as a preventive measure when there is possibility of cannibalism. In addition, only the tip of the upper beak can be removed without preventing the hens from feeding, peck the ground or clean their feathers. After that, however, Humane Farm Animal Care (HFAC) standards says that "the lower beak can be 'trimmed' (i.e, treated with heat) without removing parts of the beak to avoid its distortion when they get older" ${ }^{85}$. The concept of "trim" and the guidelines on beak trimming are confusing, contradictory and may give rise to doubt or the will of the producer; although it is not allowed, this extremely cruel and painful practice, with chronic effects, admits exceptions in some circumstances, reason why so that I highlighted this point as flawed, requiring greater detail and explanation ${ }^{86}$.

Therefore, I considered the welfare certification for laying hens provided by HFAC - Humane Farm Animal Care enough to ensure compliance with the Brazilian Federal Constitution of 1988 and Environmental Crimes Law in terms of mistreatment and cruelty prohibition. In the terms above mentioned, the welfare certification provides standards and rules that allow the laying hens to exert their natural behavior on the one hand, and, on the other hand, prohibit practices that prevent such behavior. Thus, the HFAC standards provide a high level of well-being for these birds.

However, HFAC standards have two major flaws: (1) the guidelines on debeaking, in the terms above; and (2) tolerating cage-free systems, which should be avoided, as breeding birds in closed sheds do not provide them a high level of well-being. This is why access to external areas allows the practice of natural behaviors, such as grazing, foraging, scratching and sunbathing ${ }^{87}$.

In topic 4 I will discuss the awareness of Brazilian consumers about animal welfare certification, which could be economically advantageous for egg producers as most of consumers care about animal welfare and are willing to pay more for certificated products. In addition, the increase of productivity is proportional to the increase of animal welfare.

\section{The Role and the Importance of the Consumer}

As discussed in section 3, the animal welfare certification helps to guarantee that the hens laying "certified" eggs are not mistreated or subjected to cruelty; thus, the certification ensures egg producers comply with Brazilian legislation that prohibits mistreatment and cruelty to domesticated animals such as laying hens ${ }^{88}$. However, according to David Cassuto, the lack of knowledge about the process which has transformed animals into food or in commodities led people to a passivity condition, in which they no longer consciously choose their food, but only receive what the agribusiness imposes on them. And so, this lack of knowledge has obscured the responsibility of consumers, who contribute, without knowing, with this cruel market which devastates the environment ${ }^{89}$.

According to research commissioned by the NGO World Animal Protection (WAP) in 2016, "two out of three Brazilians say they do not know how the animals whose meat is consumed by them are bred $(66 \%$ of respondents)" ${ }^{\prime 90}$. Such ignorance is due to lack of informative policies, lack of access to information ${ }^{91}$ and lack of regulation and inspection by Government body ${ }^{92}$, which implies the disregard of animal welfare by the consumer when choosing the product in the supermarket shelves.

\footnotetext{
${ }^{84}$ Ibidem., 25-26.

${ }^{86}$ LIMA, Y.F., Certificação de Bem-Estar Animal na Indústria de Ovos. 2018. Dissertação (Mestrado em Direito) - Núcleo de pesquisa e extensão em Direito ambiental e animal, Universidade Federal da Bahia, Salvador (2018) 116.

${ }^{87}$ LIMA, Y.F., Certificação de Bem-Estar Animal na Indústria de Ovos. 2018. Dissertação (Mestrado em Direito) - Núcleo de pesquisa e extensão em Direito ambiental e animal, Universidade Federal da Bahia, Salvador (2018) 117.

${ }^{88}$ BRASIL. Lei $\mathrm{n}^{\mathrm{0}}$ 9.605, de 12 de fevereiro de 1998. Dispõe sobre as sanções penais e administrativas derivadas de condutas e atividades lesivas ao meio ambiente, e dá outras providências. Diário Oficial [da] República Federativa do Brasil, Brasília, DF, 12 fev. 1998. Available in: http://www.planalto.gov.br/ccivil 03/Leis/L9605.htm (Site visited on: Sep. 17th 2017).

${ }^{89}$ CASSUTO, D., Dominando o que você come: o discurso da alimentação. Revista Brasileira de Direito Animal, v. 4, n. 5 (2009) 65 86. Available in: https://portalseer.ufba.br/index.php/RBDA/article/view/10626/7672 (Site visited on: Jun. 16th 2018 ) 84.

${ }^{90}$ ESTUDO inédito mostra percepção do consumidor latino-americano sobre bem-estar animal. World Animal Protection. 2016. Available in: https://www.worldanimalprotection.org.br/not $\% \mathrm{C} 3 \% \mathrm{ADcia} /$ world-animal-protection-lanca-estudo-inedito-sobre-bemestar-animal-e-consumo-na-america-latina (Site visited on: Dec. 16th 2017).

${ }^{91}$ MICHEL, V. - VARGAS, R.Y., O direito do consumidor à informação e o panorama atual dos selos crueltyfree no Brasil. Revista Brasileira de Direito Animal, v. 12, n. 1 (2017) 157-200. Available in: https://portalseer.ufba.br/index.php/RBDA/article/view/22023/14181 (Site visited on: Dec. 31th 2017) 174-175.

${ }^{92}$ MICHEL V.- VARGAS, R.Y., op. cit., 174.

138 Derecho Animal. Forum of Animal Law Studies, vol. 10/1
} 
However, although the widespread use of consumption relations makes consumers merely spectators with no ability to decide and monitor the consumer market, a conscious consumer would be able to discern products, services and their contractual clauses, collaborating for the rigidity of the market ${ }^{93}$.

Along these lines, researches have shown that conscious consumers, aware of production processes, would make different choices. A survey on animal testing by the cosmetics industry has shown positive results for alternatives that don't violate animals ${ }^{94}$.

Another survey, held in Florianópolis and São José, State of Santa Catarina, concluded that "the seal has $[. .$.$] an important role to the consumer [...] as consumers look at it as something that contributes to add$ true and reliable information [...]" environmental seals as informational seals is more valued, thus increasing the attractiveness of the products." 96

Another surveys, carried out in Fortaleza, State of Ceará, and Porto Alegre, State of Rio Grande do Sul, pointed out that consumers, from Social Elite to lower-middle classes would choose certified products with a specific seal accredited by controlling agencies of animal welfare ${ }^{97}$ and would also pay more for certified products which guarantee animal welfare. In the same way, the survey above mentioned, commissioned by WAP, revealed that $82 \%$ of Brazilians would buy products with animal welfare certification, and $72 \%$ would buy only those products whenever the price was the same as those products without certification ${ }^{98}$.

Another survey, conducted by the Brazilian Institute of Public Opinion and Statistics (IBOPE), showed interest growth in vegan products, and 55\% of respondents would consume more vegan products if they were better indicated in the packaging. In the capitals, this percentage rises to $65 \%{ }^{99}$.

These surveys confirm what rises Mateus Paranhos da Costa, that "there are people who wouldn't buy a product of animal origin by considering the breeding or slaughter methods inappropriate or inconvenient" 100 , that is, consumers would change their consumption habits if product packaging had clear and transparent information and, in the specific case of animal welfare and veganism, consumers would prioritize certificated products, even if it meant a higher cost.

Therefore, the increase of productivity can and should be used to benefit the welfare of laying hens, so that producers could convince themselves that it is good for their business to invest in the birds welfare and to obtain the welfare certification. The Mantiqueira group is a good example, which have increased productivity in $5 \%$ by partially implementing the cage-free system ${ }^{101}$. Thus, Michel and Vargas conclude: "If there were seals that ensure total transparency, transmitting information about all procedures performed with the animals, probably the purchase options would not be the same" 102 .

Along these lines, as a result of the first Brazilian Symposium on Welfare in Egg Production, in 2017, it was signed the Piracicaba Open Letter which, among other suggestions, had pressed for "greater transparency in the production chain, improving communication between the productive sector and society by improving food labelling rules, clearly indicating the production systems adopted and including the standardization of labelling in different levels of inspection" 103 .

\footnotetext{
${ }^{93}$ CROCE, B.B.C., Cláusulas Abusivas e o Código de Defesa do Consumidor: Interpretação como Limitação do Poder Econômico. 2010. Dissertação (Mestrado em Direito) - Programa de Pós-Graduação em Direito, Universidade Mackenzie, São Paulo, 48.

${ }^{94}$ MICHEL, V. - VARGAS, R.Y., op. cit., 2017, p. 177.

${ }^{95}$ KOHLRAUSCH, A. K., A Rotulagem Ambiental no Auxílio à Formação de Consumidores Conscientes. 2003. 153f. Dissertação (Mestrado em Engenharia de Produção) - Programa de Pós-graduação em Engenharia de produção, UFSC, Florianópolis, 136.

${ }^{96}$ KOHLRAUSCH, A.K., op. cit., 138.

97 QUEIROZ, M. L., et al. Percepção dos Consumidores sobre o Bem-Estar dos Animais de Produção em Fortaleza, Ceará. Revista Ciência Agronômica, v. 45, n. 2, p. 379-386, abr-jun, 2014. Available in: http://www.scielo.br/pdf/rca/v45n2/a20v45n2.pdf (Site visited on: Jan. 7th 2018, p. 382).

${ }^{98}$ ESTUDO inédito mostra percepção do consumidor latino-americano sobre bem-estar animal. World Animal Protection. 2016. Available in: https://www.worldanimalprotection.org.br/not\%C3\%ADcia/world-animal-protection-lanca-estudo-inedito-sobre-bemestar-animal-e-consumo-na-america-latina (Site visited on: Dec. 16th 2017).

${ }^{99}$ PESQUISA do IBOPE aponta crescimento histórico no número de vegetarianos no Brasil. Sociedade Vegetariana Brasileira. 2018. Available in: https://www.svb.org.br/2469-pesquisa-do-ibope-aponta-crescimento-historico-no-numero-de-vegetarianos-no-brasil (Site visited on: May 25th 2018).

${ }^{100}$ PARANHOS DA COSTA, M.J.R., Comportamento e bem-estar de bovinos e suas relações com a produção de qualidade. Simpósio Nacional sobre Produção e Gerenciamento da Pecuária de Corte, 2006, Belo Horizonte. Anais do IV Simpósio sobre Produção e Gerenciamento da Pecuária de Corte. Belo Horizonte-MG: Escola de Veterinária da UFMG (2006) v. 4, 02.

101 RIBEIRO, C., Maior granja de ovos da América do Sul dá liberdade às galinhas. Revista Globo Rural. 2018. Available in: https://revistagloborural.globo.com/Noticias/Criacao/Aves/noticia/2018/02/maior-granja-de-ovos-da-america-do-sul-da-liberdadegalinhas-2.html (Site visited on: March 21st 2018).

${ }^{102}$ MICHEL, V. - VARGAS, R.Y., O direito do consumidor à informação e o panorama atual dos selos cruelty free no Brasil. Revista Brasileira de Direito Animal, v. 12, n. 1 (2017) 157-200. Available in: https://portalseer.ufba.br/index.php/RBDA/article/view/22023/14181 (Site visited on: Dec. 31th 2017) 169.

${ }_{103}$ CARTA aberta de Piracicaba - bem-estar na produção de ovos. NUPEA ESALQ - USP: Núcleo de Pesquisa em Ambiência. Available in: http://www.nupea.esalq.usp.br/perfil-post/carta-aberta-de-piracicaba--bemestar-na-producao-de-ovos/1 (Site visited on: July 26th 2017).
} 
In the same sense, Mike Radford argued that "there is a need for more detailed labelling of products, so that potential buyers know what they are buying, where it came from and how it was produced. Where consumers deal, lawmakers follow." ${ }^{04}$ Also, Cassuto indicates the first step to undo the farm-factory: "We must learn to own what we eat." ${ }^{05}$ Finally, José Ciocca points out: "An important link of this chain is the consumer, who has not yet discovered the strength it possesses to move the production system. Education and awareness of ethical and sustainable production and the accessibility of this type of product are lacking" ${ }^{106}$.

Thus, all eggs produced by alternative systems should be necessarily certified with the animal welfare certification, provided that the wellness conditions were effective in breeding systems, according to the HFAC standards. The same would be observed with respect to products that use eggs. In this way, consumers would have clear and transparent information about the egg - or product that contains eggs - they want to consume and can exercise their power and citizenship.

While moving to this new stage of the animal rights, which is still within the welfarist vision, but always aiming at the abolitionism, it is necessary to emphasize the importance of the consumer's role, which always dictates the rules of the market, requiring that the companies are increasingly ethical throughout their productive chain and transparent in the labelling of their products.

Along these lines, consumers who can deprive themselves of the unnecessary consumption of eggs ${ }^{107}$ and adhere to an abolitionist vegan dietary ${ }^{108}$ will give their message to the egg industry, which will no longer exploit the layers and, perhaps, market another type of product that is more ethical and healthier. This has been occurring with the cow's milk industry, which has been replacing it with vegetable milk, free from animal mistreatment ${ }^{109}$.

\section{Conclusion}

Laying hens in Brazil rely on legal framework for their protection, although the egg industry systematically breaks these rules, especially the Federal Constitution from 1988 and the Environmental Crimes Law, which prohibit cruel practices and mistreatment. In this paradoxical scenario, the welfare certification emerges as a possibility to guarantee compliance with this legislation.

HFAC standards for laying hens, that must be followed to obtain animal welfare certification for the egg industry, are safe regarding the welfare of laying hens, except for the confused debeaking feature contained in that instrument.

However, surveys have concluded that consumers would prefer products containing animal welfare certification, even paying more for it.

This consumer power to choose certified eggs should be a stimulus for producers, as they would improve their revenue. Moreover, the laying hens' welfare would increase. It would be better for producers and laying hens. To conclude, these welfarist measures must be steps towards abolitionism, whereas the laying hens are conscious beings, subjects-of-a-life, who have the interest and the right to remain free and alive. Moreover, even the alternative and welfarist breeding systems kill all male chicks, because they are useless to the egg industry, as well as the laying hens when they are no longer productive.

\section{References}

- BAHIA. Projeto de Lei $n^{\circ} 22.223 / 2017$. Proíbe a criação de animais em sistema de confinamento no Estado da Bahia. Available in: http://www.al.ba.gov.br/atividade-legislativa/proposicao/PL./22.223/2017 (Site visited on: Sep. 14th 2017)

- BAUDUCCO anuncia política livre de gaiolas. Fórum Animal. 2018. Available in: https://www.forumanimal.org/single-post/2018/03/29/Bauducco-anuncia-pol\%C3\%ADtica-livre-degaiolas (Site visited on: Mar. 19th 2018)

\footnotetext{
${ }^{104}$ RADFORD, M., Partial Protection: Animal Welfare and the Law. In: GARNER, R. (eds) Animal Rights: The Changing Debate (London 1996) 90.

${ }^{105}$ CASSUTO, D., Dominando o que você come: o discurso da alimentação. Revista Brasileira de Direito Animal, v. 4, n. 5 (2009) 65-86. Available in: https://portalseer.ufba.br/index.php/RBDA/article/view/10626/7672 (Site visited on: Jun. 16th 2018 ) 84.

${ }^{106}$ ESTUDO inédito mostra percepção do consumidor latino-americano sobre bem-estar animal. World Animal Protection. 2016. Available in: https://www.worldanimalprotection.org.br/not\%C3\%ADcia/world-animal-protection-lanca-estudo-inedito-sobre-bemestar-animal-e-consumo-na-america-latina (Site visited on: Dec. 16th 2017).

${ }^{107}$ FELIPE, S. T., Acertos abolicionistas: a vez dos animais: crítica à moralidade especista (São José 2014) passim.

${ }^{108}$ Expression of Sonia Felipe. FELIPE, S.T., op. cit. (2014) passim.

109 EMPRESA de laticínios para de explorar animais e investe em alternativas vegetais. 2018. ANDA. Available in: https://www.anda.jor.br/2018/03/empresa-de-laticinios-para-de-explorar-animais-e-investe-em-alternativas-vegetais/ (Site visited on: Jun. 15th 2018).
}

140 Derecho Animal. Forum of Animal Law Studies, vol. 10/1 
- BRASIL. Constituição (1988). Constituição da República Federativa do Brasil de 1988. Available in: http://www.planalto.gov.br/ccivil_03/Constituicao/Constituicao.htm (Site visited on: Sep. 17th. 2017)

- $\quad$. Decreto $\mathrm{n}^{\circ} 24.645$, de 10 de julho de 1934. Estabelece medidas de proteção aos animais. Diário

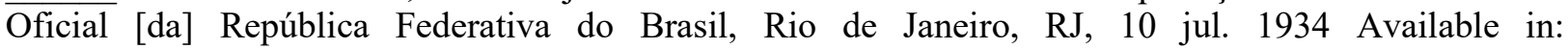
http://www.planalto.gov.br/ccivil 03/decreto/1930-1949/d24645.htm (Site visited on: Sep. 17th. 2017)

- ___ Decreto-Lei n ${ }^{\circ} 16.590$, de 10 de setembro de 1924. Approva o regulamento das casas de diversões públicas. Diário Oficial [da] República Federativa do Brasil, Rio de Janeiro, RJ, Sep. 10th. 1924. Available in: http://www2.camara.leg.br/legin/fed/decret/1920-1929/decreto-16590-10-setembro-1924-509350norma-pe.html (Site visited on: Sep. 17th. 2017)

- _. Decreto-Lei no 3.688, de 3 de outubro de 1941. Lei das Contravenções Penais. Diário Oficial [da] República Federativa do Brasil, Rio de Janeiro, RJ, 03 jan. 1941. Available in: http://www.planalto.gov.br/ccivil 03/decreto-lei/Del3688.htm (Site visited on: Sep. 17th. 2017)

- Lei $\mathrm{n}^{\circ}$ 9.605, de 12 de fevereiro de 1998. Dispõe sobre as sanções penais e administrativas derivadas de condutas e atividades lesivas ao meio ambiente, e dá outras providências. Diário Oficial [da] República Federativa do Brasil, Brasília, DF, 12 fev. 1998. Available in: http://www.planalto.gov.br/ccivil 03/Leis/L9605.htm (Site visited on: Sep. 17th. 2017)

- $\quad$. Projeto de Lei ${ }^{\circ}$ 215, de 2007. Institui o Código Federal de Bem-Estar Animal. Available in: http://www.camara.gov.br/proposicoesWeb/fichadetramitacao?idProposicao=341067 (Site visited on: Sep. 07th. 2017)

- CARGILL, fabricante das maioneses Liza e Maria, se compromete a acabar com as gaiolas em bateria para galinhas. Fórum Animal. 2017. Available in: https://www.forumanimal.org/singlepost/2017/01/13/Cargill-fabricante-das-maioneses-Liza-e-Maria-se-compromete-a-acabar-com-asgaiolas-em-bateria-para-galinhas (Site visited on: 24 dez. 2017)

- CARTA aberta de Piracicaba - bem-estar na produção de ovos. NUPEA ESALQ - USP: Núcleo de Pesquisa em Ambiência. Available in: http://www.nupea.esalq.usp.br/perfil-post/carta-aberta-depiracicaba--bemestar-na-producao-de-ovos/1 (Site visited on: July 26th. 2017)

- CARVALHO, L.C. et al. Bem-Estar na Produção de Galinhas Poedeiras - Revisão de Literatura. Revista Científica de Medicina Veterinária - Ano XIV - Número 28 - Janeiro de 2017. Available in: http://revistas.bvs-vet.org.br/rcemv/article/view/32575/40831 (Site visited on: Oct. 24th. 2017)

- CASSUTO, D., Dominando o que você come: o discurso da alimentação. Revista Brasileira de Direito Animal, $\quad$ v. $4, \quad$ n. 5 (2009), 65-86. Available in: https://portalseer.ufba.br/index.php/RBDA/article/view/10626/7672 (Site visited on: Jun. 16th. 2018)

- COSTA-FÉLIX, R. - BERNARDES, A.T., (Org.). Metrologia Vol. 1: Fundamentos. (Rio de Janeiro 2017)

- CROCE, B.B.C., Cláusulas Abusivas e o Código de Defesa do Consumidor: Interpretação como Limitação do Poder Econômico. 2010. Dissertação (Mestrado em Direito) - Programa de Pós-Graduação em Direito, Universidade Mackenzie, São Paulo.

- CUREAU, S., A Proibição Constitucional de Práticas Cruéis Contra Animais: um Mandamento Definitivo que Dispensa Qualquer Ponderação de Direitos. In: PURVIN, Guilherme (Org.). Direito Ambiental e Proteção dos Animais (São Paulo 2017)

- DIAS, E.C., A evolução da legislação de proteção animal e os movimentos sociais na pós-modernidade. In: DIAS, Edna Cardozo; SALLES; Álvaro Angelo (Org.). Direito animal: a defesa dos animais sob uma perspectiva ética, histórica e jurídica (Belo Horizonte 2017)

- EMPRESA BRASILEIRA DE PESQUISA AGROPECUÁRIA (EMBRAPA). Alternativas e Consequências da Debicagem em Galinhas Reprodutoras e Poedeiras Comerciais. Concórdia, SC: Embrapa Suínos e Aves, 2008. Available in: http://www.infoteca.cnptia.embrapa.br/bitstream/doc/444166/1/doc128.pdf (Site visited on: Jun. 15th. 2018)

- _ Circular Técnica no 49/2006. Boas Práticas de Produção na Postura Comercial. Concórdia/SC, dezembro de 2006, ISSN 0102-3713. Available in: https:/www.embrapa.br/suinos-e-aves/busca-depublicacoes/-/publicacao/443776/boas-praticas-de-producao-na-postura-comercial (Site visited on: May 10th. 2018)

- EMPRESA de laticínios para de explorar animais e investe em alternativas vegetais. 2018. ANDA. Available in: https://www.anda.jor.br/2018/03/empresa-de-laticinios-para-de-explorar-animais-e-investeem-alternativas-vegetais/ (Site visited on: Jun. 15th. 2018)

- ESTUDO inédito mostra percepção do consumidor latino-americano sobre bem-estar animal. World Animal Protection. 2016. Available in: https://www.worldanimalprotection.org.br/not\% $\%$ C3\%ADcia/world-animal-protection-lanca-estudo- 
inedito-sobre-bem-estar-animal-e-consumo-na-america-latina (Site visited on: Dec. 16th. 2017)

- FARM animal welfare council. Opinion on Osteoporosis and Bone Fractures in Laying Hens. December 2010. Available in: http://webarchive.nationalarchives.gov.uk/20110909181139/http://www.fawc.org.uk/pdf/bone-strengthopinion-101208.pdf (Site visited on: Jan. 07th. 2018)

- FELIPE, S. T., Acertos abolicionistas: a vez dos animais: crítica à moralidade especista (São José 2014)

- FOER, J.S., Comer Animais (Rio de Janeiro 2011)

- GARNER, R., Animals, Politics and Morality (Issues in Environmental Politics). (Manchester 1993)

- _ Ideologia política e o status jurídico dos animais. Revista Brasileira de Direito Animal, v. 9, n. 17, 2014, 15-40. Available in: https://portalseer.ufba.br/index.php/RBDA/article/view/12973/9280 (Site visited on: Nov. 5th. 2017)

- GORDILHO, H.J., Abolicionismo animal (Salvador 2008)

- HARARI, Y.N., Sapiens - Uma Breve História da Humanidade (Porto Alegre 2016)

- HUMANE FARM ANIMAL CARE. Manual de Diretrizes do Programa (2014)

- _. Padrões da HFAC para a Criação de Galinhas Poedeiras (2018)

- INSTITUCIONAL. ANVISA. Available in: http://portal.anvisa.gov.br/institucional (Site visited on: July 28th. 2018)

- KOHLRAUSCH, A.K., A Rotulagem Ambiental no Auxílio à Formação de Consumidores Conscientes. 2003. Dissertação (Mestrado em Engenharia de Produção) - Programa de Pós-graduação em Engenharia de Produção, Universidade Federal de Santa Catarina, Florianópolis.

- LEVAI, L.F., Direito dos animais (Campos do Jordão 2004)

- LIMA, Y.F., Certificação de Bem-Estar Animal na Indústria de Ovos. 2018. Dissertação (Mestrado em Direito) - Núcleo de pesquisa e extensão em Direito ambiental e animal, Universidade Federal da Bahia (Salvador 2018)

- MAPA - Ministério da Agricultura, Pecuária e Abastecimento. Instrução Normativa nº 3, de 17 de janeiro de 2000. Aprova o Regulamento Técnico de Métodos de Insensibilização para o Abate Humanitário de Animais de Açougue. Available in: http://www.agricultura.gov.br/assuntos/sustentabilidade/bem-estaranimal/arquivos/arquivos-legislacao/in-03-de-2000.pdf (Site visited on: Sep. 10th. 2017)

- _. Instrução Normativa ${ }^{\circ} 56$, de 06 de novembro de 2008. Estabelece os procedimentos gerais de Recomendações de Boas Práticas de Bem-Estar para Animais de Produção e de Interesse Econômico REBEM, abrangendo os sistemas de produção e o transporte. Available in: http://www.agricultura.gov.br/assuntos/sustentabilidade/bem-estar-animal/arquivos/arquivoslegislacao/in-56-de-2008.pdf (Site visited on: Sep. 10th. 2017)

- _. Portaria $n^{\circ}$ 524, de 21 de junho de 2011. Institui a Comissão Técnica Permanente para Estudos Específicos sobre Bem-Estar Animal nas Diferentes Áreas da Cadeia Pecuária. Available in: http://www.normasbrasil.com.br/norma/portaria-524-2011 233257.html (Site visited on: Sep. 10th. 2017)

- MICHEL, V. - VARGAS, R.Y., O direito do consumidor à informação e o panorama atual dos selos cruelty free no Brasil. Revista Brasileira de Direito Animal, v. 12, n. 1 (2017), p. 157-200. Available in: https://portalseer.ufba.br/index.php/RBDA/article/view/22023/14181 (Site visited on: Dec. 31th. 2017)

- NACONECY, C., Bem-Estar Animal ou Libertação Animal? Uma Análise Crítica da Argumentação AntiBem-Estarista de Gary Francione. Revista Brasileira de Direito Animal, v. 4, n. 5, 2009, 235-267. Available in: https://portalseer.ufba.br/index.php/RBDA/article/view/10633/7678 (Site visited on: Nov. $15^{\text {th }} .2017$ )

- QUE é o Inmetro. Inmetro. Available in: http://www.inmetro.gov.br/inmetro/oque.asp (Site visited on: Jun. 22th. 2018)

- ORGANISMOS acreditados. Inmetro. Available http://www.inmetro.gov.br/organismos/resultado_consulta.asp (Site visited on: May 18th. 2018)

- PARANHOS DA COSTA, M.J.R., Comportamento e bem-estar de bovinos e suas relações com a produção de qualidade. Simpósio Nacional sobre Produção e Gerenciamento da Pecuária de Corte, 2006, Belo Horizonte. Anais do IV Simpósio sobre Produção e Gerenciamento da Pecuária de Corte. Belo HorizonteMG: Escola de Veterinária da UFMG (2006) v. 4. 1-12.

- PESQUISA do IBOPE aponta crescimento histórico no número de vegetarianos no Brasil. Sociedade Vegetariana Brasileira. 2018. Available in: https://www.svb.org.br/2469-pesquisa-do-ibope-apontacrescimento-historico-no-numero-de-vegetarianos-no-brasil (Site visited on: May 25th. 2018)

- PONTES, B.C., Lei n $^{\circ}$ 11.101/11: Análise das Políticas Públicas para Animais Domésticos e Domesticados no Município de Porto Alegre. Revista Brasileira de Direito Animal, v. 7, 118-144, 2012. Available in: https://portalseer.ufba.br/index.php/RBDA/article/view/8419/6033 (Site visited on: Oct. 16th. 2017) 
- QUEIROZ, M. L., et al. Percepção dos Consumidores sobre o Bem-Estar dos Animais de Produção em Fortaleza, Ceará. Revista Ciência Agronômica, v. 45, n. 2, p. 379-386, abr-jun, 2014. Available in: http://www.scielo.br/pdf/rca/v45n2/a20v45n2.pdf (Site visited on: Jan. 07th. 2018)

- QUEM são os Certificados. Instituto Certified Humane Brasil. Available in: http://certifiedhumanebrasil.org/quem-sao-os-certificados/ (Site visited on: May 18th. 2018)

- RADFORD, M., Partial Protection: Animal Welfare and the Law. In: GARNER, R. (eds) Animal Rights: The Changing Debate (London 1996)

- REFERENCIAIS. Instituto Certified Humane Brasil. Available in: http://certifiedhumanebrasil.org/referenciais/ (Site visited on: May 18th. 2018)

- REGAN, T., Jaulas vazias: encarando o desafio dos direitos animais (Porto Alegre 2006)

- RIBEIRO, C., Maior granja de ovos da América do Sul dá liberdade às galinhas. Revista Globo Rural. 2018. Available in: https://revistagloborural.globo.com/Noticias/Criacao/Aves/noticia/2018/02/maiorgranja-de-ovos-da-america-do-sul-da-liberdade-galinhas-2.html (Site visited on: March 21 st 2018)

- RODRIGUES, D.T., Direito dos Animais e a Proteção Jurídica Brasileira. In: TOSTES, R.A. - REIS, S.T.J. - CASTILHO, V.V. (Org.). Tratado de Medicina Veterinária Legal (Curitiba 2017)

- SINGER, P., Libertação Animal (São Paulo 2010)

- SOBRE Acreditação de Organismos de Certificação. Inmetro. Available in: http://www.inmetro.gov.br/credenciamento/sobre_org_cert.asp (Site visited on: May 18th. 2018)

- TAVARES, C.R., O confinamento animal: aspectos éticos e jurídicos. 2012. Dissertação (Mestrado em Direito) - Núcleo de pesquisa e extensão em Direito ambiental e animal, Universidade Federal da Bahia, Salvador (2012) 